\title{
Linguistic, Cultural and Structural Dislocation of African Theatre: A Critical Discuss
}

\author{
Cecil Ozobeme*, Benedict Binebai \\ Theatre Arts Department, Niger Delta University, Wilberforce Island, Bayelsa State
}

*Corresponding Author: Cecil Ozobeme, Theatre Arts Department, Niger Delta University, Wilberforce Island, Bayelsa State

\begin{abstract}
The infusion of a foreign language in the social, cultural, economic and political milieu of the African people by colonial imperialist, occasioned severe dislocation on African society and African theatre. It occasioned the erosion of African indigenous language and cultural traits and engendered the abdication of African tradition performances for the hybridized Modern African theatre. This conjugal mix of western and African aesthetics and the adoption of the imperialists' language as the medium of expression occasioned the identity crisis ravaging the African theatre phenomenon. It becomes imperative that this dislocating phenomenon is examined to unravel the extent and implication of dislocation on African theatre. This paper, therefore, examines language as a dislocating factor in African theatre through a comparative analysis of traditional and contemporary African theatre forms to ascertain the nature and impact of dislocation using Binebai's dislocation theory as a frame of reference. As a remedy to the anomaly, this work recommends instituting of an authentic indigenous theatre form and critical standards or negotiating a compromise between African cultural aesthetics and western theatrical structures. The will help to constitute an African theatre that will be functional to the African society at large.
\end{abstract}

Keywords: Linguistic dislocation, African theatre, Performance, Structure and Culture

\section{INTRODUCTION}

The Balkanisation of the African space by western imperialists and the fostering on the African people a monstrously alienating and dislocated linguistic, cultural and geographical premise for existence has been very problematic for the Africans (1). Indigenous Language which suffered the most terrible blow from imperialism is an integral part of a people's culture. It is a cultural identifier of the African race, tribe, community or people. It enables identification, unification, belonging, bonding among other social-cultural considerations. Linguistically homogeneous societies share cherished cultural values and way of life ingrained in their art which reflects society. Taking into cognisance the fact that Language is one of the pivots on which communal interactivity, socialization, religion and other facets of societal life rests, it is logical to state, that the asphyxiation of a people's language as a means of expression is tantamount to the emasculation of their identity and existence [2]. This is the position with African theatre that is technically dislocated from its cultural roots, through the linguistic shift from indigenous to the imperialists' language [3]. The dislocation gets further exacerbated with the "mongrelisation of African theatre"[4] by constraining it to fit Eurocentric artistic structures and concept of theatre, evidenced in many Francophone and Anglophone African countries. It should be noted that pristine Africa theatre is unique and dynamic with a free-flowing form. It is a total theatre that blossoms with the absence of literary text, and nonconformity to alien critical aesthetic strictures. The ritualistic or secular nature of Indigenous African theatre defies spatial strictures and enables performance both on land and water. This trait accoutres it for intrinsic expression of societal values, culture, hopes, dreams and aspirations and beliefs [5] (Nkosi, 1981, 174-76). Indigenous African theatre art form is naturally constructed in a manner ingenuous to the society it serves. Panel beating it into a constricted Eurocentric artistic container will result in a high dislocation that could lead to putrefaction of the virtuous qualities embedded therein and an eventual loss of its essence. It is this crucial situation that calls for a critical examination of this abrasive dislocation to administer a panacea. Going by Binebai's dislocation theory, it behaves on the dislocated to either dislocate the dislocating factor or ascertain whether it is beneficial to negotiate a compromise that will enable coexistence with the dislocator. It is in view of above that this paper 
seeks to examine traditional and contemporary African theatre forms against the backdrop of language, culture and structure as a dislocating factor, intending to ascertaining the pros and cons of linguistic dislocation of African theatre. The findings will inform if the dislocation of African theatre need be redressed by dislocating the dislocator and ensuring a return to the status quo ante or if a negotiated compromise will be beneficial. To achieve its aim, this paper will examine the origin of this dislocation, and how it applies to African theatre. It will also analyse Binebai's dislocation theory in order to ascertain the extent of dislocation African Theatre suffers, what the pros and cons are, and how it can be remedied.

\section{ORIGin AND CONSEQUenCe OF Linguistic ANd CUltural Dislocation In AfRica}

Several factors necessitated the adoption of the western theatre form and means of expression by African dramatists. One of such factors is the exigent need for literary protestations against debilitating colonial control. The need for Africa to have a voice and a globally accepted means of self-expression, in the face of acerbic culture denigrating attacks on African way of life by western critics. The aim was to reach the intended audience and target of African artistic protestations. While the hybridized Modern African theatre, has its good points such as its usefulness in the nationalistic struggle, countering Eurocentric attacks on the black nations, accessibility to the global scene and marketability, it has several negative consequences amongst which are;

- The gradual erosion of indigenous African culture

- The near obliteration of our traditional performative elements

- The adulteration and the near eclipse of the local language of the African people

- The relegation of indigenous language from its pride of place in the artistic sphere of the African people

- The alienation of the future generation from understanding, and mastery of African traditional performance and way of life and that comes with practice.

It is the above listed, that translates as dislocation in African theatre. It will be pertinent to examine the dislocation theory.

\section{Framing The Dislocation TheORY}

Binebai's dislocation theory which can result in functional or dysfunctional manifestations, simply described, is an externally motivated dislocation resulting in a painful or none-equilibrium situation that demands immediate remediation using an equiponderate force or mechanism to dislodge or dislocate the cause of disequilibrium. For clarity sake, dislocation can be explained thus; when a healthy body get infested with a foreign body (which is the Dislocating agent) that causes disequilibrium or a diseased state, it will require the dislocation of the dislocating agent in order to regain normalcy or state of equilibrium. Aside its scientific import, the term "Dislocation" as conceived here, has social, cultural, political, literary, religious, economic and psychological implications capable of maiming, destabilising or paralysing a functioning system. Left unchecked, it can overtime, annihilate the system or bring it to extinction. Looking at the dislocation theory from the lenses of the theatre, Binebai states that the dislocation theory is crafted as intellectual scrutiny of literary authors, themes or stylistic mechanisms that are reflective of the rudiments of dislocation and destabilising approach to literary texts. This extends to dramatic or theatrical presentations, seen within regional and national backgrounds "from the flesh of language and the framing capacity of dramatic verses".[6]. The function of the playwright as a literary physician forms the bedrock of this theory because through his works the playwright subject his patient - the sick society- to critical diagnosis and uses the physical stage "as a clinic of examination and eradication of the ailment" [7]. The application of dislocation theory to theatre practice and dramatic writing is well ensconced in the prophylactic and therapeutic functions of the dramatist to society by presenting a health check on the history of his society and sometimes show how the sickness came about and proffered solution to the sickness which has dislocated his society. (8)

Binebai's dislocation theory which seems to form the bedrock of most protest dramas postulates that a dislocation left unattended has the potential of fecundating and birthing further maladies capable of dislocating the life of a people and destroying the collective destiny of the society. Of prime importance to this discussion is the origin of this dislocation theory and how it affects African theatre. 
Binebai traces the advent of this dislocation to the Balkanisation of the African space by western imperialists and the fostering a monstrously dislocated cultural and geographical entities on the African people who "till date is still suffering other forms of dislocation like ethnic and regional dislocations caused by politics of tribalism, sectionalism, and majoritarianism in Nigeria" [9]. This paper will, however, focus on the linguistic, cultural and structural dislocation of African theatre and its implications on the individual and society. To aid the discussion on linguistic dislocation, a look at language and its implication on society is necessary.

\section{LANGUAGE AND ITS IMPLICATION ON THE INDIVIDUAL AND SOCIETY}

Indigenous language or Native language refers to the language that a person acquires in early childhood as it is spoken in the family and/or it is the language of the region where the child lives. It is synonymous with mother tongue, first language, or arterial language which is inextricably linked with culture, defined as the people's total way of life [10]. It surfaces in the peoples, religion, interaction, art, and the performance of diverse activities within such a society. Language acquisition or transmission comes through observation and interaction with the environment [11]. It's relevance as a medium of artistic expression lie in its ability to aid the preservation, propagation and transmission of culture effectively. This includes different values, beliefs, norms, and other characteristics $[12,13]$, which feature prominently in the art or professional activities of the people. From the above, it follows that the sublimation one's local language could be fatally injurious to society. This is because ignorance of the language and culture of one's place marks an individual as an outsider. Again the mother-tongue is one that an individual can quickly learn and gain full proficiency or mastery compared to L2 or foreign language. It is noteworthy too, that because thinking is an avenue for acquiring knowledge, "the use of mother-tongue in which a child thinks and dreams becomes the first essential and finest instrument of human culture." [14] Its aptness in communication and expression of one's feelings and mutual exchange of ideas between tribe's men is a focal factor in the formation of a social group. It is therefore considered of high importance that, prime place be given to mother-tongue because it is an instrument of creative self-expression, emotional development, and a prime source of original ideas. [15]. Taking into cognisance the relevance of language in the life of the people, its, sublimation no doubt will have a dislocating effect on the people as they will indeed be cut off from their roots. Pertinence calls for an examination of language as a dislocating agent.

\section{Dislocation: Language and Culture as Agents}

The linguistic and cultural dislocation of African theatre has a bifocal view that affects both the pre and post-colonial African theatre. The absence of literary documentation and artistic interactions between actors in the English language is considered a dislocation by western critics since it was not assessable to those alien to African culture [16]. The perception of the west of theatre, demands to have performance areas or stage space in a structured theatre hall, a script with a storyline that has a well-articulated plot structure and mimesis translated to mean interacting actors expressing the ideas of a playwright using body and voice [17] All of these are what Eurocentric literary critics find partially absent in traditional African theatre.

Linguistic dislocation in post-colonial African theatre is evident in the cultivation of an alien language as a means of expression in the theatre and the adaptation of foreign theatrical standards and structures. Following the balkanization of the African continent the imperialist in the bid to muster total control over annexed African countries in the administrative, social, religious and cultural spheres, denigrated the African way of life and brandished western styled civilisation for the colonies to imbibe [18] [19]. For a linguistically diverse society like Nigeria with over five hundred languages and dialects [20] it was imperative to adopt the different but homogenous means of expression if one must participate in trade and other fields of human endeavour outside one's community. The imperialists' western styled religion, education and governance were administered in English with little or no effort expended in cultivating the local language by the side. Resultantly, African culture suffered disorientation and alienation [21 and 22], Overtime, the humiliation, subjugation and exploitation of the black race coupled with the massive ideological devaluation and attacks against the intimate subjective dignity of colonised Africans [23] saw the ascription of superiority to everything western and what is African was considered inferior. In the area of the theatre, African dramatist took to the western form of writing and play creation done in English and French and tailored after the 
Aristotelian concepts of theatre. The pristine traditional African theatre was gradually relegated to the background [24], and several performative elements and forms whittled down as the new form could not accommodate them. In the present day, these forms have been left to those in the rural areas, leaving many youths in the presently residing in urban centres, culturally dislocated because they can hardly speak their native language and barely understand the tradition and culture of their roots. [25] Literary scholars like Wali has in time past questioned the rationality of this shift and condemned the use of foreign language and performance styles that alienates the people about whom they were made [26] Other evident elements of dislocation lie in the attempt at transcription of certain indigenous words, phrases, idioms metaphors and proverbs which lose their meaning and message when translated literarily to English or French. Before colonial adventurism in Africa, Africans identified with the natural form content and context of indigenous performances and were sordidly disoriented by modern theatre forms. This gave rise to the contention that modern African theatre has lost its 'Afrikaness' and should be referred to as Afro- European theatre [27]. It is evident here that language and culture are real agents of dislocation. Further understanding of the dislocation of African theatre requires a look at the nature of African theatre in the pre and post-colonial era.

\section{NATURE OF Traditional AFrican Theatre}

The polemics surrounding the existence of an African theatre is not novel in African literary discourses. It accounts for contrasting opinions and disputations as to what constitutes African theatre. While several critics contend that Africa has no theatre, others vehemently hold that Africa has an authentic and identifiable art form which is being denied recognition just because it does not conform to western critical standards. However, the traditional African theatre often called precolonial theatre is that which predates the imperialist incursion into Africa. It is a non-literary total theatre that embraces some, if not all artistic elements in performance such as dance, music, costume and makes, puppetry, mask and masquerade, acrobatic displays, oratory, invocation and incantations, ritual display and other social, ceremonial performances. It is made manifest in festivals, initiation rites, for both the male and female gender, symbolic hunting and war preparation performances as well as funeral performances in honour of the dead and other social ceremonies such as traditional marriage, hospitality rites etc. [28]. These various performances which literary theorists like Schechner, Turner and Bakare Traore claim are entertaining and productive, serves other multiple functions. They are educative, have aesthetic appeal and can be classified as a social drama. African Traditional theatre also serves political purposes though criticism of errant rulers and leaders. It is a tool for mobilisation through the instigation of collective action. Lastly, it helps history through the recollection of significant past events and the glorification and deification of past communal heroes. In summing up those mentioned above, African theatre is a prop for the knowledge production, philosophy enactment, as well as a means for reflections on situations and occurrences, defining and reinventing of themselves and their social world, and resisting, reinforcing, reaffirming or subversion of prevailing social order [29].

\section{CONTEMPORARY AFRICAN THEATRE}

The crisis of identity plaguing contemporary African theatre is linkable to the view that it is a product of western theatre aesthetics. In contrast to the Traditional African theatre that is purely African in concept and execution, contemporary African theatre is a hybrid theatre that Africans can hardly lay claim to because it applies the Aristotelian aesthetic prescriptions, a foreign language medium and is performed in a western styled theatre hall.[30]. To worsen the already exacerbated position is the continuous attempt by African dramatists to structure and constrain African theatre performances to fit Eurocentric literary codifications. It is an observable fact that this hybrid modern African theatre does not in any way capture the essence of the pristine traditional African theatre either in form or in content. J.P Clark's attempt with the play Ozidi and Soyinka's attempt with A Dance of the Forest and Death and the Kings Horseman, though a laudable effort to capture the essence of African theatre, can be described as old wine in new wineskins. It is this abnormality that has fecundated the advocacy for a truly African theatre devoid of western trappings.

A comparative analysis of the pro and postcolonial African theatre

A comparative analysis between the theatres of both eras will elucidate the point of dislocation being made here. 
- Traditional African theatre is a total theatre that is participatory, involving the elimination of the dividing lines between actors and audience. Contemporary African theatre shows a clear delineation between audience and actors occasioned by the western styled theatre hall or stages

- Traditional African theatre is indigenous and assessable to all because it is done in the language of the people and it is one the people can identify with irrespective of class status, age social disposition and level of education. The Contemporary African theatre of the other hand is considered elitist because it is done in English language and is selective of its audience who must have some level of literary competence or education in other to comprehend it. [31]

- Traditional African theatre is. It is not the product of a crafted dramatic text or play script. This means that no individual can claim authorial rights for the performance [32]. The homogeneity of performance which comes sometimes yearly, as is the case with festivals, is achieved through communal participation, observation, practice and mastery [33](Wilson,1973: 160). Contemporary African theatre, on the other hand, is textual documentation of a playwright's idea. Here subjectivity becomes the bane as what is relayed is the ideas of the author which can be historically incorrect or erroneous. It is for this reason that some plays on the same subject do have different accounts. An example is Ola Rotimi's Kurumi and Wale Ogunyemi's Ijaye Wars dealing with the same event. Ovonramwen Nogbaise is a play that has two different accounts of the same subject matter. Such contradictory reports have no place in the traditional theatre where the unwritten script emanates from the society itself and is past down orally to future generations.

- Traditional African theatre is a social drama involving the entire community it serves as a cultural tribunal where disputes are settled and erring member of society are judged and punished or vindicated. This is evident in several African narratives like Chinua Achebe's "Things fall apart" where the masquerade dancers sat in judgement over Okonkwo's accidental killing of a clansman. Another example is the fidelity rites common among several African communities where an adulterous wife is made to confess and perform a cleansing ritual or purification rites before the elders and ancestors. Traditional African theatre is born out of the people's cultural way of life and as such is of intrinsic value to them both socially, politically, religiously and morally. It has a tie-in between the past the present and the future. Consequently, it is efficacious and aids societal regeneration, preservation and continuum. It is not a fee-paying event and is open to all. Contemporary African theatre, on the other hand, does not fully qualify as social drama in that replication of such an event as described above on stage would be sheer mimesis devoid of the ritual efficacy. It is most times a fee-paying performance for a select audience selective that the theatre hall can contain.

- Traditional African theatre is not constrained by time and space. Some traditional performance types like festivals could last for days or weeks. This makes room for several types of performance packages in one production. The Contemporary African theatre does not allow for the extended time duration permissible by traditional African theatre because it is tailored after the Aristotelian codification of the theatre which stipulates adherence to the unity of time which most of the elite audience have become used to.

From the foregoing it is clear that there is a paradigm shift from what was truly an African theatre to the hybrid form we have as contemporary African theatre comprising a mix of western and indigenous aesthetics. This position, however, raises several salient questions begging for answers. How can this dislocation be remedied? Is there a need for Africa to develop a purely indigenous African theatre form without recourse to western theatrical structure, language and staging techniques? Does the "hybridisation" evident in contemporary African theatre disqualify it as theatre? Will it be better to negotiate a compromise between the old and new form as an African form? An examination of the pros and cons of both theatre forms may be instrumental in finding a solution to this artistic impasse

\section{REMEDYing THE Dislocation OF AFRICAN THEATRE}

A look at the foregoing in this discourse, two probable solutions presents itself as a panacea to the issue of dislocation. First is the need for a purely African theatre that captures the essence of traditional African performance without recourse to western theatre aesthetic, language and structure as postulated by Fanon [34]. This type of theatre which Dada (2003:36) defines as "works done by Africans for Africans" is what Ngugi wa Thiongo vehemently supports by advocating the strict use of local language for African theatre [36] because they are indicative of Africa's' rich traditions. 
The second is negotiating a compromise between African and western aesthetics and structures with a modification of the structures to accommodate more of the performance aesthetics of the African culture and people as proffered by the likes of Achebe, Chinwezu and a host of others. The proffered solutions has their pros and cons. Revert to the pristine African theatre will also have a shortfall in linguistic universality taking into consideration the fact that the world is now a global village that embraces intellectual, social, technological, convergence and exchange of ideas and knowledge. This remedy will localise African content and restrict them to their immediate environment. The linguistic and cultural diversities of most African societies like Nigeria with semantic heterogeneity will narrow the audience to a particular geographical location since it will be incomprehensible to others outside the immediate communities [37]. Besides, the literary and academic nature of contemporary African theatre that enabled a response to western critics will be lost. Marketing African art forms will also be problematic in a global market because a more significant part of the world will be linguistically alienated. However, some critics who are positively disposed to an authentic theatre may argue that as far as typology is concerned, authentic African theatre, globalised as a localised form, would be appreciated [38]. Several African musics rendered in some indigenous African language has to appeal for foreign audiences. The Ipi tombi dance of South Africa, a piece of indigenous African music and dance performance was enjoyed all around the world even though it is made up of purely African elements ranging from language to costume and dance steps. For Africa to toe this line would require a redefinition and documentation of African forms and structures in addition to African oriented aesthetic standards or critical criteria, that would guide the evaluation and appreciation of authentic African theatre art form.

The second option which proffers a mix between western African aesthetics with a more significant percentage of African inputs will do well if a modus operandi is initiated for the inclusion of several pristine African performative elements and an artistic ideology that will capture the essence of true African theatre. This modification will be reflected in language, the structure of the stage space or performance areas and style. It will also affect all other parts of the theatre, which needs to be manipulated in a manner that will give it a distinct style distinguishable from the western styled theatre that is tied to the Aristotelian codification. It is hoped that these suggestions may inspire further studies on this issue that will sooner or later help resolve the dislocation problem of African theatre.

\section{SUMMARY}

This paper examines the controversies surrounding African theatre as an autonomous and dynamic theatre form. The paper argues that the polemics of identity may be attributed to structural, cultural and linguistic dislocations in African theatre occasioned by the balkanization of the African space and subsequent denigration and attacks on African theatre. An examination of the language phenomenon was made with highlights of its relevance to society, the individual and the theatre. It went on to look at Binebai's dislocation theory intending to using it as a frame of reference in the bid to find a solution to the dislocation problem suffered by African theatre. Pre and Postcolonial African theatre were analysed and a comparative analysis was done to show the point of convergence and divergence so to aid finding of a solution to the impasse. It was discovered that the fate of African theatre lies with Africans and proffers two plausible solutions which are: Reverting to the pre-colonial theatre instead of a hybrid mix of African and European aesthetics. The second is a negotiated compromised between the African and western aesthetics with the proviso that a modification is made that will ensure more inputs of African indigenous culture and philosophy.

\section{CONCLuSion}

The polemics of identity caused by the seeming aberrant adoption of a foreign language as a medium of expression in African theatre still has a long way to go in getting resolved. While factors like imperialism, modernisation and globalisation have been fingered as the reason d'être for the dislocation of the African theatre, this paper argues that the chief dislocating factor is linguistic, cultural and structural. Dislocating the English language and reverting to the use of indigenous language will ensure a shift back to the status quo preceding the infiltration by the colonial adventurist. It will to a high extent gain authentication for modern African theatre as genuinely African. However, the advantage of accessibility, marketing and comprehension which a language medium with universal spread can achieve in the global sphere will be lost. Negotiating a compromise between African and western aesthetics seems to be the other plausible solution provided 
it undergoes serious modifications that will enable the infusion of the cultural-historical and philosophical aspects of African people. Where these do not find a good ground, then it will be left to having both forms exist side by side and looked at as different types of African theatre.

\section{RECOMMENDATIONS}

It is highly recommended that more studies be carried in this field to investigate ways by which African theatre can have its autonomy from western theatre aesthetics. Again it will help the course of African theatre if institutions of learning incorporate in their curriculum, studies in indigenous African cultural and aesthetic performance and practices so that they will not be alienated from their root. This way will acquire the cultural competence to appreciate, comprehend and cherish indigenous African theatre. The government of the day in several African countries need to create an enabling environment for indigenous African theatrical performance to thrive rather than relegating it to the background. Lastly, the media should be involved in globalising and marketing localised African performances through media exposure and interpretation. This will add value and create an appeal for indigenous African theatre outside the shore of the countries from which they emanate.

\section{REFERENCES}

[1] Alu, Nachafiya. N. "Between New Challenges in African Literature and Contemporary Realities: the Case Study of Opanachi's Eaters of the Living." African Research Review, Ethiopia Vol. 5 no 4, Serial No. 21, July, 2011, Pp. 342-353 (Conference proceeding)

[2] Nwadike, I. U. Igbo Language and culture: Whither bound? Chief (Dr) F. C. Ogbalu Memorial Lectures, (1 \& 3), Onitsha: Varsity Press and Unizik, 2008. 9 (Lecture)

[3] Ngugi, wa Thiong'o. "Europhonism, Universities, and the Magic Fountain: The Future of African Literature and Scholarship." Research in African Literatures, vol. 31, no.1, 2000 pp1-11. (Conference proceeding)

[4] Dandaura, Emmanuel. S. Negotiating Identity: Theatre, Performance and Criticism in Africa. International Association of Theatre critics. 2017. p 5 Retrieved from http://www.iatc.com.hk/doc/10086925/6/2018 (Conference proceeding)

[5] Nkosi, Lewis. Tasks and Masks Themes and Styles in African Literature. Harlow, Essex: Longman, 1981:174-76 (Book)

[6] Binebai, Benedict. Aesthetics of dislocation: Towards a protest drama theory in Post-colonial Africa. 2018 (Unpublished Book in progress)

[7] (Binebai, p5) Ibid p5

[8] (Binebai, 9) Ibid p9

[9] (Binebai, 6). Ibid p6

[10] Newhill, E.E. and U. La Paglia. Exploring world culture. Lexington, Mass: Ginn. 1986 (Book)

[11] Kottak, C. P. Cultural Anthropology (10th ed). New York: McGraw-Hill. 2004 (Book).

[12] Igwe, U. A., \& B. Adeyemi. Concept of Culture and Early Cultural Centres in Nigeria. Edited by B. Adeyemi. Nigeria people and culture (pp. 18-20). Ogun state Nigeria: Babcock University Press. 2011 (Book Chapter)

[13] Scupin, R. Cultural anthropology: a Global Perspective (6th ed). New Jersey: Prentice Hall, Inc. 2006. (Book)

[14] Kioko, Angelina. Why schools should teach young learners in home British Council. org/ voicesmagazine/why-schools-should-teach-young-learners-home-language. 2015(Patent)

[15] Bell, Granham Four stroke performance tuning in theory and practice. Foulis and co Ltd 1981 pp 158159 (Book)

[16] Etherton, Michael, The development of African drama 1982: Cited in African Popular Theatre: From Pre-colonial Times to the Present Day by David Kerr. Heinemann, 1995, ch. 6 p124 (Book chapter)

[17] Finnegan, R . Oral Literature in Africa. London: Oxford University Press, 1970 (Book)

[18] Alu, Nachafiya. N. "Between New Challenges in African Literature and Contemporary Realities: the Case Study of Opanachi's Eaters of the Living." African Research Review, Ethiopia Vol. 5 no 4, Serial No. 21, July, 2011, Pp. 342 (Conference)

[19] Binebai, 2012:6).

[20] Ajepe, I and A. J. Ademowo. "English language dominance and the fate indigenous language in Nigeria." IJHCS International Journal of History and Cultural Studies Vol. 2, no.4, 2016, PP 10-17 (Conference proceeding)

[21] Illo, Isaiah "Language in Modern African Drama" CLCWeb: Comparative Literature and Culture vol.8,4. 2006, pp 2 of 9. (Conference proceeding) 
[22] Sirayi, Mzo. South African Drama and Theatre from Precolonial Times to 1990s: An Alternative Reading. Xlibirsi, Bloomington. 2012 (Book)

[23] Irele, Abiola, Cited in African Popular Theatre: From Pre-colonial Times to the Present Day by David Kerr. Heinemann, 1995, Ch. 6, p 126 (Book chapter)

[24] (Binebai 2012:6),

[25] Mowarin, Macaulay. "Language Endangerment In Urhoboland." A paper presented at the Fifth Annual Conference of Urhobo Historical Society held at PTI Conference Centre, Effurun, Delta State, Nigeria, and Ibru Centre, Agbarha-Otor, Nigeria, October 29-31, 2004. (Conference proceeding)

[26] Wali, Obi., 'The dead-end of African literature', Transition, (10 September 1963), 13 - 15 cited in African Languages and African Literature by Cecilia A. Eme \& Davidson U. Mbagwu, 2011, p117 (Conference proceeding)

[27] ibid

[28] Amankulor, Ndukaku and Chinyere Okafor. "Continuity and the Change in TransitionalNigerian Theatre among the Igbo in the era of colonial politics" Ufahamu, Vol. 26, no. 3, 1988, 35-50 (Conference proceeding)

[29] Drewal, Margaret. The state of research on performances in Africa. African studies review 34:3 Dec. 1991, 1-64 (Conference proceeding)

[30] Dandaura, Emmanuel. S. Negotiating Identity: Theatre, Performance and Criticism in Africa. International Association of theatre critics. 2017. Retrieved from http://www.iatc.com.hk/doc/100869 25/6/2018 (Conference proceeding)

[31] Illo, Isaiah "Language in Modern African Drama" CLCWeb: Comparative Literature and Culture vol.8,4. 2006, pp 2 - 9. (Conference proceeding)

[32] Nkosi, Lewis. Tasks and Masks Themes and Styles in African Literature. Harlow, Essex: Longman, 1981:174-76 (Book)

[33] Wilson, M. Quoted in Sirayi, Mzo. South African Drama and Theatre from Precolonial Times to 1990s: An Alternative Reading. Xlibirsi, Bloomington. 2012(Book)

[34] Fanon, Frantz. The Wretched of the Earth. New York: Grove Press, 1963. P17-18). (Book)

[35] Dada, Pius Olusegun. "The Tradition of the African Novel”. Modern Essays on African Literature: Studies in the African Novel Vol 1. Samuel Omo Asein \& Albert Olu Ashaolu. Ibadan: Ibadan UP, 1996. $27-$

[36] Nnolim, Charles. Issues in African Literature. Lagos: Malthouse Press 2010 p1 (Book)

\section{TITLES FOR FURTHER READING}

[1] Achebe, Chinua. "The African Writer and the English Language." Morning Yet on Creation Day. By Chinua Achebe. London: Heinemann, 1975. 55-62.

[2] Asagba, A. I. "Roots of African Drama: Critical Approaches and Elements of Continuity, Kunapipi, 1986. vol 8 no.3,. Available at: http://ro.uow.edu. au/kunapipi/vol8/iss3/16

[3] Amankulor, Ndukaku and Chinyere Okafor. "Continuity and the Change in Transitional Nigerian Theatre among the Igbo in the era of colonial politics" Ufahamu, Vol. 26, no. 3, 1988, 35-50

[4] Chinweizu, J. O. and I, Madubuike. Toward the Decolonization of African Literature, Vol. I, Enugu, Fourth Dimension Publishers, 1980.

[5] Clark, J.P. Ozidi. Oxford University Press, London, 1966.

[6] Crystal, D. English as a global language. Cambridge: Cambridge University Press. 1997

[7] Drewal, Margaret. The state of research on performances in Africa. African studies review 34:3 Dec. 1991, 1-64

[8] Etherton, Michael 'Zambia- Popular Theatre', in New Theatre Magazine, 12, ii, 1972, p. 20.

[9] Fanon, Frantz. The Wretched of the Earth. New York: Grove Press, 1963. p17-18).

[10] Finnegan, R . Oral Literature in Africa. London: Oxford University Press, 1970

[11] Kioko, A. Why schools should teach young learners in home britishcouncil. org/ voices-magazine/whyschools-should-teach-young-learners- home- language. 2015

[12] Krama, I. C . "Theatrical Performance as Social Work in Nigeria." IJAH, International Journal of Arts and Humanities Bahir Dar- Ethiopia Vol. 6, no. 2, S/No 21, April, 2017: 41

[13] Kottak, C. P. Cultural Anthropology (10th ed). New York: McGraw-Hill. 2004

[14] Matsebula, J.S.M. History of Swaziland. Maskew Miller Longman, South Africa, 1987. pp337.

[15] Mlama, Penina M., Culture and Development: The Popular Theatre Approach in Africa, Uppsala, Sweden: The Scandinavian Institute of African Studies, 1991.

[16] Mollel, Tololwa M., “African Theatre and the Colonial Legacy: Review of the East African Scene”. Utafi ti: Journal of the Faculty of Arts and Social Sciences, vol. 7, no. 1, 1985, pp. 20-29. 
[17] Ngugi, wa Thiong'o. Writers in Politics. London: Heinemann, 1981.

[18] Ogunyemi, wale. Ijaye War (In the Nineteenth Century)Published by Ibadan: Orisun Acting Editions, 1971

[19] Rotimi O (1974). Ovonramwen Nogbaisi. Benin City: Ethiope Publishing Corporation

[20] Rotimi O (1971). Reprint. 1988. Kurunmi. Ibadan: university Press Plc.

[21] Soyinka, Wole. Dance of a forest. London, Oxford, 1963

[22] --- Death and King's Horseman. London: Methuen, 1975.

[23] Turner, Victor. From Ritual To Theatre: The Human Seriousness Of Play, New York: Performing Arts Journal Publications, 1982.

[24] Ukpai, M.O. and E.U. Orji. Literature in Nigerian languages: "A potent tool in democratic Nigeria" JONLAC 4.2002, 13-16

\section{AUTHORS' BIOGRAPHY}

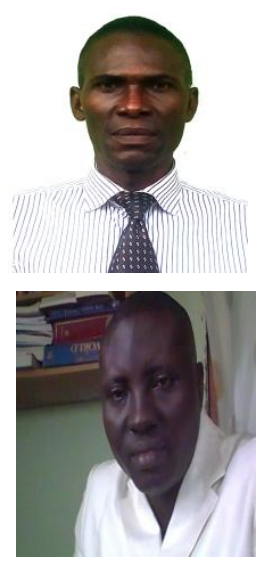

Cecil Ozobeme is a Lecturer and erstwhile Head of Department of the Theatre Arts Department of the College of Education Warri, Delta State, Nigeria. He is currently pursuing a doctorate degree in Theatre Arts at the Niger Delta University, Bayelsa State. He is a theatre Artist involved in the theory and practice of theatre arts in Nigeria. He is also director and a scriptwriter who has served as an accredited resource person with the National Board for Technical Education (NBTE.)

Benedict Binebai (PhD), a literary scholar, Educated at the University of Ibadan. $\mathrm{He}$ is a playwright, an author and academic, an Associate Professor of drama, dramatic theory and criticism in the Department of Theatre Arts Niger Delta University, Wilberforce Island Bayelsa with Research interest in critical theories and traditional African performances.

Citation: Cecil Ozobeme, Benedict Binebai. "Linguistic, Cultural and Structural Dislocation of African Theatre: A Critical Discuss "International Journal on Studies in English Language and Literature (IJSELL), vol 7, no. 1, 2019, pp. 14-22. doi: http://dx.doi.org/10.20431/2347 -3134.0701002.

Copyright: (C) 2019 Authors. This is an open-access article distributed under the terms of the Creative Commons Attribution License, which permits unrestricted use, distribution, and reproduction in any medium, provided the original author and source are credited. 